\title{
Financial Information Related to Dynamic Capabilities - The Corporate Innovation Platform
}

\author{
Stefan Schiller (Corresponding author) \\ School of Business, Society and Engineering, Mälardalen University \\ PO Box 883, SE 72123 Västerås, Sweden
}

Tel: 46-21-107-039Ｅ-mail: stefan.schiller@mdh.se

$\begin{array}{lc}\text { Received: October 8, } 2013 & \text { Accepted: October 28, } 2013 \quad \text { Published: October 30, } 2013 \\ \text { doi:10.5296/rbm.vli1.4496 } & \text { URL: http://dx.doi.org/10.5296/rbm.vli1.4496 }\end{array}$

\begin{abstract}
The purpose of this paper is to suggest an empirically based model for identification, recognition and measurement of internally generated intangible assets (IIAs) that meets the fundamental qualitative characteristics of useful financial information. The paper sets out to empirically test observed relations reflecting new product development activities and their economic consequences in listed companies, by means of personal interviews with senior managers, selected on the basis of their knowledge in the specificities of the innovation process in their firm by means of a phenomenographic analysis the identified relations are conceptualized in terms of logically related categories. There seems to be a match between the identified observed relations and the recognition requirements that International Accounting Standard (IAS) 38.57 sets out, which indicates that the requirements are relevant and information meeting the requirements may faithfully represent what it purports to represent or reasonably can be expected to represent. By relating the recognition and measurement of IIAs to the proposed model the linkage between IIAs and related organizational mechanisms will be made more explicit which may improve the representational faithfulness of the financial information. One of the practical implications of this study is that an entity specific control system based on the recognition criteria presented in paragraph IAS 38.57 can improve the robustness of recognized IIAs arising from innovative activities. By building a bridge between the dynamic capability literature and the accounting literature the paper develops a new model of how to account for IIAs.
\end{abstract}

Keywords: internally generated intangible assets, recognition and measurement, corporate innovation platform 


\section{Introduction}

This paper tackles the challenge of how to equate accounting for intangible assets regardless of how they are acquired. The focus is set on internally generated intangible assets (IIAs). By building a bridge between the dynamic capability literature and the accounting literature the paper develops a new model of how to account for IIAs. Thereby actionable insights will be uncovered. An intangible asset (IA) is by definition an economic resource, that is, "something that is scarce and capable of producing cash inflows or reducing cash outflows, directly or indirectly, alone or together with other economic resource" (IASB/FASB, 20 October, 2008). The literature on the resource-based view (RBV) on the entity and its extension of the dynamic capabilities framework tend to use a plethora of terms, such as: resources, assets, intangible assets (IAs), capabilities and competences, without arriving at a consensus of the meaning of the terms (Danneels, 2002, p. 1102). The RBV of the entity claims that resources that are simultaneously valuable, rare, imperfectly imitable and imperfectly substitutable (VRIN) are a source of competitive advantage (Barney, 1995, 2001). VRIN resources may enable an entity to achieve sustained competitive advantage. The dynamic capability framework extends the RBV argument by addressing how VRIN resources can be created and how the current valuable resources can be reconfigured and used in complex and volatile external environments (Ambrosini \& Bowman, 2009, p. 29; Barney, 2001). However, and importantly, contrary to VRIN resources dynamic capabilities should have key features in common to be effective, but in terms of details they can be different (Eisenhardt \& Martin, 2000 , p. 1110). These differences refer to the synergetic interaction of dynamic capabilities caused by the way competences vary between entities (Witcher \& Chau, 2007, p. 532).

\subsection{The Rationale for the Proposed Model}

The dynamic capability view (DCV) of the entity is ultimately about understanding an entity's growth and survival, that is, how resources evolve over time and how advantage is sustained despite, or maybe more correctly, owing to an environment that is in a constant state of flux (Ambrosini \& Bowman, 2009). Several authors make use of basic accounting concepts, however without explicating the meaning of concepts such as asset, tangible asset and IA (e.g., Dierickx \& Cool, 1989; Kogut \& Zander, 1992; Markides \& Williamson, 1996; Barney, 1986, 1991; Peteraf, 1993; Teece et al., 1997; Teece, 2007). This raises questions about the conceptual grounds of RBV and DCV. From an accounting perspective, the insights from RBV and especially DCV might be helpful in developing or improving our understanding of the elusive accounting concept of IAs, and IIAs in particular. Given that dynamic capabilities are directed at the creation of future resources (Ambrosini \& Bowman, 2009, p. 39), and that dynamic capabilities are mechanisms by which entities learn and accumulate new skills and capabilities (Teece et al., 1990, p. 11; Helfat et al., with Maritan, 2007), dynamic capabilities may be seen as mechanisms for generating IAs in general, and IIAs in particular (Teece, 2007).

Dynamic capabilities actually consist of identifiable and specific routines, or "processes that use resources - specifically the processes to integrate, reconfigure, gain and release resources - to match and even create market change" (Eisenhardt \& Martin, 2000, p. 1107). Teece et al. 
(1997) define a dynamic capability as an ability to renew competences to achieve a fit with a changing business environment. However, there is little guidance on how this relates to the valuation of intangible resources and how firm-specific features can be taken into account (Teece, 2007:1329). Despite the fact that accounting for IIAs has been the subject of much debate over the last 20 years or so (for a summary, see for example Skinner, 2008; Hand \& Lev, 2003) little progress has been made in terms of new accounting standards. Regarding the debate, the dividing line seems to be between those who favor reliability over relevance, versus those who take the opposite stand. Those who favor reliability argue that there is a risk that some managers might recognize IAs lacking an underlying economic value in order to inflate the statement of the financial position, or others might postpone the recognition of discovered assets in order to expand future operating results by avoiding future amortization. Those who favor relevance argue that current recognition and disclosure practices related to IAs need to be reformed in order to increase the predictive ability of the financial reports. Skinner (2008) discusses what distinguishes broadly defined IIAs (i.e., intangible economic resources) from those assets recognized under current accounting regulation. These characteristics include that: (1) many intangible economic resources are not separate, saleable, or discrete items; (2) they are hard to associate with well-defined property rights; (3) it is difficult to reliably estimate fair values for these types of resources; and (4), consequently, it is often difficult to write fully-specified contracts (ibid, p. 203).

Upton (2001, p. 109) states that improved financial reporting will inter alia require recognition of IIAs in financial statements and improved measures for those assets. By and large, current accounting statements recognize IAs only when they are acquired in a business combination or individually. Upton (2001, p. 107) concludes that there is no conceptual basis in the definition of an asset for applying different recognition rules to IAs purchased from others and the same assets created internally (see also Reilly \& Schweihs, 1999). Upton suggests that accounting standard-setters should develop a basis for the recognition and measurement of IIAs (ibid., p. 3).

At a conceptual level, Upton's inference is reinforced by the improved and converged conceptual framework where the fundamental qualitative characteristics of useful financial information are said to be "relevance" and "faithful representation" (IASB and FASB, 28 September 2010). The IASB and the U.S. Financial Accounting Standards Board (FASB) have come to the conclusion that prudence or conservatism is no longer a sub-quality of faithful representation as it conflicts with neutrality. The ingredients of primary decision-specific qualities of relevance and faithful representation are "comparable, verifiable, timely, and understandable", leaving out, for example, the quality of prudence or conservatism. The Boards conclude that conservatism is incompatible with neutrality (IASB, 2007, April). In the view of Riahi-Belkaoui (2004, p. 187) neutral financial information is free from bias toward attaining some desired result. According to the IASB the objective of financial reporting is "to provide financial information about the reporting entity that is useful to existing and potential investors, lenders, and other creditors in making decision about providing (economic) resources to the entity" (IASB, Conceptual Framework, Chapter 1, 28 September 2010). According to the Comprehensive Business Reporting Model (CFA Institute, 
2007), investors require clear and complete disclosure of IAs held by an entity, which is in line with Upton's suggestion.

According to IAS 38.57 development costs are capitalized only after the technical and commercial feasibility of the asset for sale or use have been established. This means that the entity must intend and be able to complete the IA and either use it or sell it and be able to demonstrate how the asset will generate future economic benefits. This paper assumes that the burden of proof related to establishing technical and commercial feasibility of an asset will be easier to bear if the entity can make a direct reference to a robust model of innovation, based on dynamic capabilities. Given that the R\&D, software, and product development may be conceived as an innovation process directed at the creation of future resources, the dynamic capability view may be used as a theoretical concept linking this innovation process to the identification, recognition, and measurement of IIAs.

The overriding purpose of this paper is to suggest an empirically based model for accounting for IIAs that meets the fundamental qualitative characteristics of useful financial information, given the overriding principle of "equal should be treated equally". The specific purpose is to identify linkages between IAS 38.57 criteria and a model of the enterprise's innovation process, perceived from a senior management perspective. By identifying an empirically based model founded on a system of dynamic capabilities and external economic factors, a corporate innovation platform, which drives intangible resources related to new products and services, the identification, recognition and measurement of IIAs is assumed to be more reliable. By relating the recognition and measurement of IIAs to the system of dynamic capabilities the financial information is assumed to be more relevant and able to give a more faithful representation. From an accounting point of view, the recognition and measurement differences between particular types of IAs will become less significant. This, in turn, may affect the robustness of accounting judgments related to IAs (Ashton \& Hubbard Ashton, 2007).

The focus is set on initial rather than subsequent accounting for IIAs in order to keep the scope of the paper manageable. The paper adopts Keys and Ardern's (2008:3) definition of "initial" to mean "accounting for an IIA commences at the start of, and occurs up to completion (or abandonment) of, its creation". The scope of the paper is further limited to the category of IIAs that are created in much the same way as tangible assets, e.g., research and development (R\&D), software, and product development (c.f. Upton, 2001). The paper argues that such gradual recognition of category by category may be a more efficient strategy than adopting more radical changes to existing requirements (Key \& Ardern, 2008). Insights from this first category may be drawn upon when developing into the categories that are more complicated in terms of identification, recognition, and measurement. The rest of the paper is presented in six sections. Section two explains the methodology and research design. Section three reports the results of eleven in-depth personal interviews with senior managers in 10 companies. Section four provides an analysis and discussion of the results and some concluding remarks are in the fifth and final section. 


\section{Methodology and Research Design}

A model explains how factors interact with each other in order to have an effect on the performance considered. Setting out from the perspective of product innovation speed, Filippini et al. (2004: p. 201) assert that only a few studies have emphasized that the effect of one driver on performance may depend on another driver. Furthermore, they conclude that there is "a lack of extensive empirical research on whether the interactions between different factors affect time performance". In a study that ranks 24 technology management issues of new product development (NPD) in terms of importance, Scott $(2000$, p. 63) finds that "few, if any, of the new product development (NPD) technology management issues are essentially separate from other issues...". He continues, “...this suggests that, to gain a good perspective on the NPD technology management field requires that some of the issues need to be thought of in an interrelated manner" (ibid). Scott's conclusion is in line with Griffin's (1997: p. 452) observation that the best NPD entities appear to focus on simultaneously improving several managerial aspects of NPD. This indicates that in order to implement and foster the factors of innovation, firms should have a clear understanding of the way the factors interact.

In a survey study Schiller et al. (2004) identify relations that conceptualize dynamic capabilities and external economic factors that drive intangible resources related to new products and services. These observed relations cover three perspectives: time-to-market (the development phase in R\&D, or innovation time (Granstrand, 1999)); number of innovations/patents (the research phase in $\mathrm{R} \& \mathrm{D}$ ); and margin per new product (the financial aspect of the definition of innovation). These different perspectives of innovativeness are not unproblematic, in that, for example, reducing the time-to-market may create competitive advantages, but may also lead to the development of technologically inferior products (Kahn, 2004; Cooper \& Edgett, 2008). However, over time the market forces are assumed, at least to some extent, to leverage out deviations from what is expected (cf. the notion mean reversion). The survey study adopted an interdisciplinary or integrative approach (Rhodes \& Wield, 1994; Tidd et al., 2001) derived from the fields of strategy, business management, management of technology, industrial economics, and organizational behaviour. A corporate innovation platform was formulated (see Appendix 1) that includes an extensive list of internal and external factors that are considered crucial to the vast number of people who are involved in the management of product development.

Each factor was described from the three different dimensions (time-to-market for a new product, margin per new product, and the number of patents/innovations per new product). Senior managers of 40 listed Swedish firms were surveyed to find out how they perceived the impact of each factor in the model on the degree of innovativeness. In order to measure the linkage between the three dimensions of the dependent variable and each of the factors (independent variables) a spearman's rho was calculated for each pair of variables. Identified correlations significant at the .01 or .05 level were transformed into observed relations. The survey study identified 10 observed relations related to the time-to-market per new product dimension, 7 observed relations associated with the margin per new product dimension, and 8 observed relations connected to the number of patents/innovations per new product dimension. From this bulk of observed relations, two observed relations from each dimension 


\section{Macrothink}

have been selected for empirical validation on the basis of how participants ranked them.

The two observed relations ${ }^{1}$ related to the dimension time-to-market per new product are presented in Table 1, whereas the observed relations linked to the dimension margin per new product can be seen in Table 2. Finally, Table 3 displays the observed relations related to the dimension number of patents/innovations per new product. In the remainder of this paper the empirical validation of the identified observed relations will be dealt with.

Table 1. Observed relations associated with the dimension time-to-market per new product (Schiller et al., 2004)

\section{$\underline{\operatorname{Dev}-1}$}

Competitive Environment/Market Position correlates with:

A General economic outlook *, $\mathrm{N}=40$ (Positive)

B Systems for Evaluation and Reward/Personnel Policy **, $\mathrm{N}=40$ (Negative)

$\underline{D e v-2}$

Involvement of customers/users/suppliers in the R\&D/innovation process correlates with:

A Educational and knowledge level within the $\mathrm{R} \& \mathrm{D} /$ innovation function **, $\mathrm{N}=40$ (Positive)

$\mathrm{B}$ Integration and coordination of the Marketing and $\mathrm{R} \& \mathrm{D} /$ innovation function * $\mathrm{N}=40$ (Positive)

C Methods of funding R\&D/innovation activities **, $\mathrm{N}=40$ (Positive)

Table 2. Observed relations connected with the financial dimension per new product (Schiller et al., 2004)

\section{Fin-3}

Competitive Environment/Market Position correlates with:

A Margin per new product **, $\mathrm{N}=38$ (Positive)

B Corporate strategy**, $\mathrm{N}=38$ (Negative)

$\mathrm{C}$ Management model - including the measurement system *, $\mathrm{N}=38$ (Negative)

\section{Fin-4}

Involvement of customers/users/suppliers in the $R \& D /$ innovation process correlates with:

A Management model - including the measurement system **, $\mathrm{N}=38$ (Positive)

B Educational and knowledge level within the $\mathrm{R} \& \mathrm{D} /$ innovation function **, $\mathrm{N}=38$ (Positive)

C Proximity to Science Park (like IDEON, Chalmers Science Park) *, N = 38 (Positive)

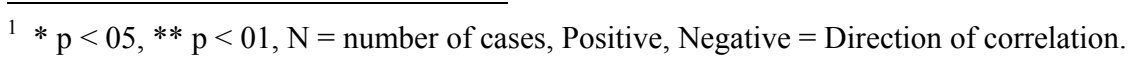




\section{Macrothink Institute ${ }^{\text {TM }}$}

$\mathrm{D}$ Involvement of senior management in $\mathrm{R} \& \mathrm{D} /$ innovation process **, $\mathrm{N}=38$ (Positive)

E Integration and coordination between idea generation and product development **, $\mathrm{N}=38$ (Positive)

Table 3. Observed relations linked to the research dimension per new product (Schiller et al., 2004)

$\underline{\operatorname{Res}-5}$

Corporate Culture/innovation climate correlates with:

A Methods of funding $\mathrm{R} \& \mathrm{D} /$ innovation activities *, $\mathrm{N}=35$ (Positive)

$\underline{\operatorname{Res}-6}$

Corporate strategy correlates with:

A Management model - including the measurement system *, $\mathrm{N}=36$ (Positive)

B Alliance/partnership/innovation networks/licensing with other companies *, $\mathrm{N}=36$ (Positive)

C Methods of funding R\&D/innovation activities *, $N=35$ (Negative)

The present paper sets out to further investigate these relations for new product development activities and their economic consequences in listed companies on NASDAQ OMX Stockholm, by means of eleven in-depth personal interviews with senior managers, selected on the basis of their knowledge in the specificities of the innovation process in the firm the senior manager represents. By means of a phenomenographic analysis (Marton, 1981, 1986; Marton \& Booth, 1997; Åkerlind, 2005) the identified relations are conceptualized in terms of logically related categories. Together, the conceptualized identified relations form a corporate innovation platform that can be dynamically governed by an enterprise in order to generate intangible assets. The conceptualized identified relations may be understood or interpreted by means of guidelines or rules of thumb (heuristics) that may link the observed relations to the requirements that IAS.57 sets out (c.f. Kahneman et al., 1982; Gilovich et al., 2002; Ashton \& Ashton, 1995).

\section{Data Collection}

The interviewees were carefully selected on the basis of their demonstrated experience of conducting $R \& D$ research on senior management level. The interviewees represent different types of companies, ranging from large technical companies, medium-sized technical companies, medium-sized IT companies to large medical technology companies. In total, 10 companies were selected, of which the category "large technical companies" forms the majority. A total of 11 persons were interviewed, 1 interview at each company except for 1 company (F7) in which 2 interviews were conducted due to the vast technology diversified nature of research and development in this company. With the exception of 1 telephone interview (F2) and 1 interview at a university location (F5), all the remaining interviews were 
carried out at the interviewee's office. The interviews lasted on average 71 minutes, with a time span ranging from a maximum of 165 minutes (F5) to a minimum of 30 minutes (F10). If the extreme values are excluded, the time span ranges from 45 minutes to 75 minutes, with an average of 64 minutes. Some of the interviewees were efficient in responding to the questions, while other interviewees tended to have a more elaborate way of responding to the questions. All of the interviewees, however, responded to the questions in a very insightful and professional way. Of the observed relations, 5 percent were not considered relevant by the respondents on the ground that they did not reflect a relevant relationship. For example, not all the companies operate in the vicinity of a science park or have an open product market (for example, the defense industry).

The interview questions referred to identified relations related to the time-to-market (development) (Dev1 and Dev2), margin per new product (financial) (Fin3 and Fin4), and number of patents/innovations per new product (research) (Res5 and Res6). Each relation relates one major phenomenon or factor (for example, competitive environment/market position) to one to five statements, each containing one sub-phenomenon (see Appendix 2). First, the interviewee was asked to indicate on a seven-point Likert scale the strength of the covariation between the major phenomenon and the sub-phenomenon (see Appendix 9). The interviewee was urged to indicate secondly the direction (if any) of the covariation and thirdly whether the strength of the covariation has changed over time, and if so, the circumstances in which this has taken place. Finally, the interviewee was asked to give an example of how the major phenomenon may be associated with the particular sub-phenomenon in question.

The quantitative element of the data collection aims to identify those observed relations that are considered to be relevant by the interviewees. The selection criterion for the observed relations is that the median (on a seven-point Likert scale) falls between $1 \geq$ and $>3.5$ (see Appendix 3). In some instances the interviewees indicated that the response to a particular relation falls between two points on a Likert scale, for example, between point 3 and point 4 (which is represented by the figure 3.5 in Appendix 3). Those observed relations that fall between $1 \geq$ and $>3$ are termed general observed relations, whilst observed relations with a median of 3 are termed special observed relations. That is, the general observed relations are considered to reflect a stronger covariation than the special observed relations.

Three general observed relations related to the development perspective are selected (Dev1-A, Dev2-A, and Dev2-B), whereas five observed relations within the marginal perspective (Fin3-A, Fin3-B, Fin3-C, Fin4-A, and Fin4-D) meet the criterion. Three observed relations (Res5-A, Res6-B, and Res6-C) within the innovation-level perspective also meet the selection criterion. The corresponding observed relations within the category special observed relations are (Dev1-B, Fin4-B, Fin4-E, and Res6-A).

\section{Analysis}

By means of a phenomenographic method, the identified relations are substantiated and given an empirical meaning. Phenomenographic research aims to investigate the qualitatively different ways in which people understand or conceptualize a particular phenomenon or an 
aspect of the world (see, for example, Åkerlind, 2005; Marton \& Pong, 2005). These different ways of understanding or conceptualizing form the basic unit of description (categories of description), which are further analyzed with regard to their logical relations in forming an outcome space (Marton \& Pong, 2005). This outcome space, ideally, represents the spectrum of all the possible ways of experiencing the studied phenomenon, at a particular point in time, for the population represented by the interviewees collectively ( $\AA$ kerlind, 2005). Marton and Pong (2005) distinguish between two intertwined aspects of conception, one global and one specific aspect: the referential aspect, which refers to the global or overall meaning; and the structural aspect of the conception, which refers to elements of phenomena in the specific context simultaneously reflected upon by the interviewees.

The phenomenographic analysis involves the following steps. First, the interviewees were encouraged to reflect on the interview questions/observed relations. After the interviews, they were transcribed and the questions/observed relations considered relevant by the interviewees were identified (relevance has to be considered from covariation perspective). Then the interviewees' answers/reflections were structured to each identified question/observed relations according to the way in which the interviewees were reasoning (forming the model of reflection). A distinction was made between statements on the hypothesized covariation, balancing factors related to the hypothesized covariation, and, the context in which the balancing factors operate. Statements related to the context were given by the interviewees when they felt that they needed to put their reflection into perspective. The regular statements are statements on the hypothesized covariation and balancing factors. The interviewees also gave clarifying statements related to these statements. These clarifying statements are subordinate statements relative to the latter types of statements (hierarchy of statements).

This model of reflection forms the basis for analyzing the interviewees' reflections, that is, how the reflections may be interpreted and categorized.

The reflections related to the following relations (listed in Appendix 2):

Dev1-A, Dev1-B, and Dev2-A,

Dev2-B

Fin3-A, Fin3-B, Fin3-C, Fin4-A,

Fin4-B, Fin4-D, and Fin4-E

Res5-A, and Res6-A, Res6-B, Res6-C [observed relations related to the product

Development process - development lead time]

[observed relations to the Financial side of product

development/innovation - margin per new product]

[observed relations to the level of $\underline{\text { Research - }}$ number of patents/innovations per new product]

Each regular statement linked to an identified relation/question is then given a number. For each number, clarifying statements pertaining to that statement are recognized (see Appendix 
4). Balancing factor statements are recognized by their keyword or main word (according to the "geist" of the statement). These keywords or main words are categorized into one of seventeen factors, and each factor is categorized into one of three levels depending on its frequency of occurrence (see Appendix 5 to 8).

Overall, the most important balancing factor is know-how/intellectual work, that is, knowledge and intellectual property rights. This factor occurs more than twice as many times as the factors ranked second. This is especially true firstly for observed relations related to the level of innovation (Res5 - Res6), and secondly for observed relations related to the economic side of product development/innovation (Fin3 - Fin4). Besides product characteristics, factors related to management and activities come second. This holds particularly for observed relations related to the economic side of product development/innovation. The factors at the second level, financial and strategy seem to be rather evenly distributed across the three different perspectives, whereas the relatively infrequent occurrence of the factors pertaining to the third level appears, to a great extent, to relate to the development perspective (Dev1 - Dev2) rather than the innovation-level perspective (Res5 - Res6). Within the financial perspective (Fin3 - Fin4), the factors at the first level dominate the distribution of the factors in a more tangible way than in the other perspectives.

Knowledge and intellectual property rights, management, activities, and product characteristics seem to have an explicit connotation and meaning within the economic perspective. From the literature, one might expect the development perspective to dominate the occurrence of the management and activities factors. One explanation might be that the economic view tends to feed through the management and activities factors. Relatively, factors such as culture, networking, ownership structure, and system tend to occur frequently within the innovation-level perspective; this may indicate that the covariation related to the number of patents/innovations per new product is complex and multifaceted. This in itself requires the inclusion of different factors.

All of the identified relations but one (Res5-A) relate predominantly external factors (competitive environment/market position (Dev1 - Dev2), customers/users/suppliers (Fin3 Fin4), and corporate strategy (Res6) to the innovation process/new products. Res5-A relates the corporate culture/innovation climate to the methods of funding of innovative activities. Hence, Res5-A may be perceived to mirror a more internal perspective compared with the rest of the observed relations. Despite this external focus of the identified relations, the interviewees make use of just a few market-linked balancing factors (for example, customer, market, and trend), with low frequency (use) of each balancing factor. Instead, the interviewees tend to ascribe meaning to the identified relations by using predominantly internal balancing factors such as know-how/intellectual work, corporate operation, management, product development, and product. That is, the interviewees tend to take an internal perspective to explain the meaning of the identified relations.

Out of the seventeen identified relations, the interviewees tend to consider that fifteen of them are relevant in the sense that there is a significant covariation. Taken together, these 
fifteen relations may form a model regarding the product development process/innovation activities relevant to proprietary projects or internally generated intangible assets. According to IAS 38.57, an intangible asset arising from development shall be recognized if an entity can demonstrate (a) technological feasibility, $(b-c)$ the intent and ability to use or sell the intangible asset, (d) probable future benefits, (e) the resources to complete the intangible asset, and (f) the ability to measure the reliability-related cost. Therefore, which relation supports which recognition requirements $(a-f)$ ? Recognition criterion (a) requires technical feasibility to complete the intangible asset so that it will be available for use or sale.

(a) The recognition criterion may be supported by the following (general) relations: Dev2-A, Dev2-B, Fin4-A, Fin4-D, Res5-A, Res6-B, and Res6-C. The higher the education and knowledge level within the $\mathrm{R} \& \mathrm{D} /$ innovation function, the more likely it is that customers/users/suppliers will be involved in the development process, which, in turn, will decrease the development lead time (Dev2-A). Similarly, the higher the level of involvement of customers/users/suppliers in the development process, the higher the level of integration between the marketing function and the $\mathrm{R} \& \mathrm{D} /$ innovation function, which, in turn, will decrease the development lead time (Dev2-B).

The decreased development time indicates the technical feasibility of completing the intangible asset so that it will be available for use or sale.

The higher the level of involvement of customers/users/suppliers in the development process, the more elaborated the management model will be - including the measurement system, which, in turn, will have a positive impact on the margin per new product (Fin4-A), and the higher the level of involvement of senior management in the $\mathrm{R} \& \mathrm{D} /$ innovation process will be. This, in turn, will have a positive impact on the margin per new product (Fin4-D).

The increased involvement of customers/users/suppliers in the development process indicates, via a positive impact on the margin per new product, the technical feasibility of completing the intangible asset so that it will be available for use or sale.

The higher the level of corporate culture/innovation, the more effective the methods of funding $\mathrm{R} \& \mathrm{D} /$ innovation activities will be. This, in turn, will have a positive impact in terms of patents/innovations per new product (Res5-A). The higher the level of the corporate strategy, the higher the level of the alliance/partnership/innovation networks/licensing with other companies will be. This in turn, will have a positive impact in terms of patents/innovations per new product (Res6-B). There is also a positive relation between the level of the corporate strategy and the methods of funding $R \& D /$ innovation activities, which, in turn, will have a positive impact in terms of patents/innovations per new product (Res6-C).

Management-controlled correlations that have a positive impact in terms of patents/innovations per new product indicate the technical feasibility of completing the intangible asset so that it will be available for use or sale.

(b) The entity's intention to complete the intangible asset so that it will be available for use or sale may be supported by (general) relations Fin3-B, Fin4-D, and Res6-B. The more exposed the competitive environment/market position, the higher the level of corporate strategy, 


\section{Macrothink}

which, in turn, will have a positive impact on the margin per new product (Fin3-B). The higher the involvement of customers/users/suppliers in the development process, the higher the level of involvement of senior management in the R\&D/innovation process, which, in turn, will have a positive impact on the margin per new product (Fin4-D). The higher the level of corporate strategy, the higher the level of the alliance/partnership/innovation networks/licensing with other companies, which, in turn, will have a positive impact in terms of patents/innovations per new product (Res6-B).

An explicit corporate strategy and a high level of involvement of senior management in the $\mathrm{R} \& \mathrm{D} /$ innovation process indicate the entity's intention to complete the intangible asset so that it will be able for use or sale.

(c) The entity's ability to use or sell the intangible asset may be supported by (general) relations Dev2-A, and Fin4-A.The higher the education and knowledge level within the $\mathrm{R} \& \mathrm{D} /$ innovation function, the more likely it is that customers/users/suppliers will be involved in the development process, which, in turn, will decrease the development lead time (Dev2-A). Also, the higher the level of involvement of customers/users/suppliers in the development process, the more elaborated the management model - including the measurement system, which, in turn, will have a positive impact on the margin per new product (Fin4-A).

Dev2-A, and Fin4-A are indicative of the entity's ability to use or sell the intangible asset on the grounds that decreased development lead time and a positive impact on the margin per new product are assumed to facilitate the use or sale of the subject intangible asset. The entity's ability to use or sell the subject intangible asset is assumed to be facilitated by decreased development lead time and a positive impact on the margin per new product.

(d) By referring to (general) relations Dev1-A, Dev2-A, Fin3-A, Res6-B, and Res6-C, it will be easier for the entity to demonstrate how the intangible asset will generate future economic benefits. The rationale for this assertion is that by controlling the mechanisms that are closely connected to the development lead time, margin per new product, and number of patents/innovations per new product, the entity will be in the position to demonstrate how the subject intangible asset will generate future economic benefits.

(e) By referring to the (general) relations Dev2-A, Dev2-B, Fin4-D, Fin4-E, Res5-A, Res6-B, and Res6-C, it will be easier for the entity to demonstrate the availability of adequate technical, financial, and other resources to complete the development and to use or sell the subject intangible asset. The basis for this claim is that by controlling the mechanisms for an efficient development process and a positive margin per new product, and demonstrating how the patents/innovations per new product are to be financed the entity makes it likely that it will have access to adequate resources.

(f) The entity's ability to measure reliably the expenditure attributable to the subject intangible asset during its development is strengthened by referring to (general) relations Fin3-C and Fin4-A. The rationale for this claim is that by fine-tuning the management model, including the measurement system, with the market position, involvement of 
customers/suppliers/users in the development process, the entity demonstrates its ability to measure reliably the expenditure attributable to the subject intangible asset during its development.

The analysis indicates that by referring to an integrated system of identified relations the entity can increase the probability that the subject intangible asset will generate future economic benefits. Hence, descriptive information about the integrated system of identified relations can improve the information users' ability to evaluate the nature and potential financial effects of internally generated intangible assets. The conceptualized identified relations may related to a unique context by means of company specific guidelines, or rules of thumb (heuristics) in that they offer a way to economize on cognitive faculties (Kahneman et al., 1982; Gilovich et al., 2002; Ashton \& Ashton, 1995). The balancing factors may indicate the focal point of guidelines, or rules of thumb given the identified relations, and in their extension, the recognition requirements given by IAS 38.57.

\section{Conclusion}

The literature concludes that there is no conceptual basis for applying different recognition rules to intangible assets purchased from outsiders and the same assets created internally (Upton, 2001; Reilly \& Schweihs, 1999). This paper has formulated a model for accounting for internally generated intangible assets in the form of an integrated system of identified relations. Each identified relation reflects a dynamic capability. By relating the recognition and measurement of internally generated intangible assets to the proposed model the linkage between IIAs and related organizational mechanisms will be made more explicit which may improve the representational faithfulness of the financial information. Thereby, from an accounting point of view, the recognition and measurement differences between particular types of IAs will become less significant, which, in turn, may affect the robustness of accounting judgments related to IAs. The analysis suggests that decisions regarding the recognition and measurement of internally generated intangible resources in a dynamic environment could be improved by referring to this integrated system of identified relations. Thereby, the qualitative characteristics of useful descriptive information in financial statements in terms of relevance and faithful representation will also become more articulated. This indicates that the same recognition rules can be applied to intangible assets purchased from others, intangible assets acquired in a business combination and intangible assets created internally.

There seems to be a match between the identified relations and the recognition requirements that IAS 38.57 sets out, which indicates that the requirements are relevant and information meeting the requirements may faithfully represent what it purports to represent or reasonably can be expected to represent. The balancing factors may indicate how the identified relations are contextualized, which, in turn, may give point of references to the recognition requirements given by IAS 38.57. This indicates that an entity specific control system based on the recognition criteria presented in paragraph IAS 38.57 can improve the robustness of recognized internally generated intangible assets arising from innovative activities.

The IASB calls for policy-relevant academic research and other forms of academic input into 
the standard-setting process regarding internally generated intangible assets. This paper offers a model for accounting for internally generated intangible assets that may be useful for the IASB's standard-setting endeavors. The integrated system of identified relations, the corporate innovation platform, can be used by management as a system of mechanisms for controlling or managing internally generated intangible assets. The disclosed information about this integrated system of identified relations enables users of financial statements to evaluate the nature and potential financial effects of the entity's activities regarding internally generated intangible assets.

Keys and Arden (2008, p. 24) conclusion that intangible items of the same nature, irrespectively of whether they are acquired in a business combination or internally generated, could be analyzed in the same with a view to determining whether they are assets, is based on a purely hypothetical assumption. The authors admit that their proposal is significantly different from the specific recognition requirements in IAS 38 .51-61. Instead, this paper sets out from the recognition criteria given by IAS 38.57 as a point of reference, and identifies those mechanisms that have to be in place in order to meet the recognition criteria. In this way, no hypothetical assumption has to be formulated. Furthermore, this paper offers insights for managerial and organizational practices as well in that the proposed model indicates what mechanisms should be focused on and balanced in order to establish a robust corporate innovation platform.

\section{Acknowledgements}

The research is financed by Handelsbanken's Research Foundations, No. P2010-0039:1. Thanks to Professor Ignace De Beelde for help and suggestions.

\section{References}

Adler, N. (1999). Managing complex product development: Three approaches. Ph.D. dissertation, Stockholm: EFI, Stockholm School of Economics.

Ambrosini, V., \& Bowman, C. (2009). What are dynamic capabilities and are they a useful construct in strategic management? International Journal of Management Reviews, 11, 29-49. http://dx.doi.org/10.1111/j.1468-2370.2008.00251.x

Andrews, K. R. (1998). The concept of corporate strategy. In H. Mintzberg, J. B. Quinn, \& S. Ghoshal (Eds.), The strategy process. (Chapter 3, pp. 51-60, Revised European ed.). London: Prentice Hall.

Ashton, R. H., \& Hubbard Ashton, A. (2007). Judgment and decision-making research in accounting and auditing. Cambridge: Cambridge University Press.

Barney, J. B. (1986). Strategic factor markets: Expectations, luck and business strategy. Management Science, 32, 1231-1241. http://dx.doi.org/10.1287/mnsc.32.10.1231

Barney, J. B. (1991). Firm resources and sustained competitive advantage. Journal of Management, 1, 99-120. http://dx.doi.org/10.1177/014920639101700108

Barney, J. B. (1995). Looking inside for competitive advantage. Academy of Management 


\section{$\triangle$ Macrothink}

Executive, 9, 49-61.

Barney, J. B. (2001). Is the resource-based 'view' a useful perspective for strategic management research? Yes. Academy of Management Review, 26, 41-56.

Buchholz, R. A., \& Rosenthal, S. B. (2002). Technology and business: Rethinking the moral dilemma. Journal of Business Ethics, 41, 45-50. http://dx.doi.org/10.1023/A:1021346021768

Carroll, A. B., Lipartito, K. J., Post, J. E., Werhane, P. H., \& Goodpaster, K. E. (2012). Corporate responsibility: American experience. Cambridge: Cambridge University Press. http://dx.doi.org/10.1017/CBO9781139108041

Christensen, C. M., \& Bower, J. L. (1996). Customer power, strategic investment, and the failure of leading firms. Strategic Management Journal, 17, 197-218. http://dx.doi.org/10.1002/(SICI)1097-0266(199603)17:3\%3C197::AID-SMJ804\%3E3.0.CO; $2-U$

Clark, K., \& Fujimoto, T. (1991). Product development performance: strategy, organization, and management in the world auto industry. Boston: Harvard Business School Press.

Cohen, W. M., \& Levinthal, D. A. (1990). Absorptive capacity: a new perspective on learning and innovation. Administrative Science Quarterly, 35, 128-152. http://dx.doi.org/10.2307/2393553

Cooper, R., \& Slagmulder, R. (1999). Develop profitable new products with target costing. Sloan Management Review, 40, 23-33.

Cooper, R. G., \& Kleinschmidt, E. J. (1993). Major new products: what distinguished the winners in the chemical industry? Journal of Product Innovation Management, 10, 90-111. http://dx.doi.org/10.1016/0737-6782(93)90002-8

Cooper, R. G., \& Edgett, S. J. (2008). Maximizing productivity in product innovation. Research-Technology Management, 51, 47-58.

Crawford, C. M. (1997). New products development. (4th ed.). Burr Ridge: Irwin.

D’Aveni, R., \& Ravenscraft, P. (1994). Economies of integration vs. bureaucracy: does vertical integration improve performance? Academy of Management Journal, 37, 1167-1206.

Daily, C. (1996). Is the customer always right? Effects of customers' influence on product development strategies. The Academy of Management Executive, 10, 105-106.

Danneels, E. (2002). The dynamics of product innovation and firm competence. Strategic Management Journal, 23, 1095-1121. http://dx.doi.org/10.1002/smj.275

Das, T. K., \& Teng, B. S. (2003). Partner analysis and alliance performance. Scandinavian Journal of Management, 19, 279-308. http://dx.doi.org/10.1016/S0956-5221(03)00003-4

Dierickx, I., \& Cool, K. (1989). Asset stock accumulation and sustainability of competitive advantage. Management Science, 35, 1504-1511. http://dx.doi.org/10.1287/mnsc.35.12.1504 


\section{Macrothink}

Research in Business and Management

ISSN 2330-8362

2014, Vol. 1, No. 1

Eisenhardt, K. M., \& Martin, J. A. (2000). Dynamic capabilities: what are they? Strategic Management

Journal, 21 ,

1105-1121.

http://dx.doi.org/10.1002/1097-0266(200010/11)21:10/11\%3C1105::AID-SMJ133\%3E3.0.C

$\mathrm{O} ; 2-\mathrm{E}$

Filippini, R., Salmaso, L., \& Tessarolo, P. (2004). Product development time performance: investigating the effect of interactions between drivers. Journal of Product Innovation Management, 21, 199-214.

Friedman, M. (1997). The social responsibility of business to increase its profits, in T. L. Beauchamp \& N. E. Bowie. (eds.). Ethical theory and business (5th ed.). Englewood Cliffs: Prentice Hall.

Gilovich, T., Griffin, D., \& Kahneman, D. (Eds.). (2002). Heuristics and biases: The psychology of intuitive judgment. New York: Cambridge University Press. http://dx.doi.org/10.1017/CBO9780511808098

Gomes, J., Weerd-Nederhof, P. de, Pearson, A., \& Fisscher, O. (2001). Senior management support in the new product development process. Creativity and Innovation Management, 10, 234-242. http://dx.doi.org/10.1111/1467-8691.00226

Granstrand, O. (1999). The economics and management of intellectual property: Towards intellectual capitalism. Cheltenham: Edward Elgar.

Griffin, A. (1997). PDMA research on new product development practices: updating trends and benchmarking best practices. Journal of Product Innovation Management, 13, 429-458. http://dx.doi.org/10.1016/S0737-6782(97)00061-1

Hand, J., \& Lev, B. (2003). Intangible assets: values, measures and risks. Oxford: The Oxford Management Readers, Oxford University Press.

Helfat, C. E., Finkelstein, S., Mitchell, W., Peteraf, M. A., Singh, H., Teece, D. J., ... Maritan, C. (2007). Dynamic capabilities and organizational processes. In C. E. Helfat, S. Finkelstein, W. Mitchell, M. A. Peteraf, H. Singh, D. J. Teece, \& S. Winter (Eds.). Dynamic capabilities: understanding strategic change in organizations (Chapter 3). London: Blackwell.

Henderson, D. (2001). Misguided virtue. Wellington: New Zealand Business Roundtable; and London: The Institute of Economic Affairs.

IASB/FASB. (2008a). Joint meeting 20 October, Conceptual framework, Phase B: Elements and Recognition, Norwalk.

Jagersma, P. K. (2003). Innovate or die. Journal of Business Strategy, 24, 25-28. http://dx.doi.org/10.1108/02756660310508236

Johnson, G., \& Scholes, K. (1993). Exploring corporate strategy. Hemel, Hempstead, Hertfordshire: Prentice Hall.

Kahneman, D., Slovic, P., \& Tversky, A. (Eds.). (1982). Judgment under uncertainty: Heuristics and biases. New York: Cambridge University Press. 


\section{Macrothink

Karlsson, C., \& Åhlström, P. (1997). Perspective: changing product development strategy: A managerial challenge. Journal of Product Innovation Management, 14, 473-484. http://dx.doi.org/10.1016/S0737-6782(97)00063-5

Keys, R., \& Ardern, D. (2008). Initial accounting for internally generated intangible assets, Staff Discussion Paper, Australian Accounting Standards Board.

Kogut, B., \& Zander, U. (1992). Knowledge of the firm, combinative capabilities, and the replication of technology. Organization Science, 3, 383-387. http://dx.doi.org/10.1287/orsc.3.3.383

Krugman, P. (2009). The return of depression economics and the crisis of 2008. New York: W. W. Norton \& Company.

Leenders, M., \& Wierenga, B. (2001). The effectiveness of different mechanisms for integrating marketing and R\&D. The Journal of Product Innovation Management, 19, 305-317. http://dx.doi.org/10.1016/S0737-6782(02)00147-9

Leonard-Barton, D., \& Sinha, D. K. (1993). Developer-user interaction and user satisfaction in internal technology transfer. Academy of Management Journal, 36, 1125-1139. http://dx.doi.org/10.2307/256649

Link, A. N., \& Link, K. R. (2003). On the growth of U.S. Science Parks. Journal of Technology Transfer, 28, 81-85. http://dx.doi.org/10.1023/A:1021634904546

Mansfield, E. (1969). The economics of technological change. London: Longmans.

Markides, C. C., \& Williamson, P. J. (1996). Corporate diversification and organizational structure: A resource-based view. Academy of Management Journal, 39, 340-367. http://dx.doi.org/10.2307/256783

Marton, F. (1981). Phenomenography: describing conceptions of the world around us.Instructional Science, 10, 177-200. http://dx.doi.org/10.1007/BF00132516

Marton, F. (1986). Phenomenography: A research approach to investigating different understandings of reality. Journal of Thought, 21, 28-49.

Marton, F., \& Booth, S. (1997). Learning and awareness. Hillsdale, New Jersey: Lawrence

Erlbaum.

Marton, F., \& Yan Pong, W. (2005). On the unit of description in phenomenography. HigherEducation Research \& Development, 24, 335-348.

Massey, D., Wield, D., \& Quintas, P. (1991). High-tech fantasies: Science parks in society, science and space. London: Routledge.

McGee, J. E., \& Dowling, M. J. (1994). Using R\&D cooperative arrangements to leverage managerial experience. Journal of Business Venturing, 9, 33-48. http://dx.doi.org/10.1016/0883-9026(94)90025-6 


\section{Macrothink

Mintzberg, H. (1998). The innovative organization. In H. Mintzberg, J. B. Quinn, \& S. Ghoshal (Eds.), The strategy process. (Chapter 12, 707-723, Revised European ed.). London: Prentice Hall.

Mitchell, G. R., \& Hamilton, W. F. (1988). Managing R\&D as a strategic option. Research-Technology Management, May-June, in IRI (1994), Measuring and improving the performance and return on R\&D. Washington, DC: IRI, 86-93.

Mothe, J. de la, \& Link, A. N. (2002). Networks, alliances and partnerships in the innovation process. Dordrecht: Kluwer Academic Publishers. http://dx.doi.org/10.1007/978-1-4615-1151-9

Narayanan, V. K. (2001). Managing technology and innovation for competitive advantage. New Jersey: Prentice Hall.

Nixon, B. (1998). Research and development performance measurement: A case study. Management Accounting Research, 9, 329-355. http://dx.doi.org/10.1006/mare.1998.0079

O'Reilly, C. A. (1989). Corporate culture considerations based on an empirical study of high growth firms in Silicon Valley. Pisa: Economia Aziendale, Università degli Studi di Pisa. 3/3.

Oden, H. W. (1997). Managing corporate culture, innovation, and intrapreneurship. Westport: Quorum Book.

Pavitt, K. (1990). What we know about the strategic management of technology. California Management Review, 32, 17-26.

Pavitt, K. (1991). Key characteristics of the large firm. British Journal of Management, 2, 41-8.http://dx.doi.org/10.1111/j.1467-8551.1991.tb00014.x

Penrose, E. T. (1959). The theory of the growth of the firm. Oxford: Basil Blackwell.

Peteraf, M.A. (1993). The cornerstones of competitive advantage: A resource-based view. Strategic Management Journal, 14, 179-191. http://dx.doi.org/10.1002/smj.4250140303

Porter, M.E. (1985). Competitive advantage: Creating and sustaining superior performance. New York: Free Press.

Porter, M. E. (1996). What is strategy? Harvard Business Review, 74, 61-78

Porter, M. E. (1998). On competition. Boston: Harvard Business School Publishing.

Quinn, J. B. (1985). Managing innovation: controlled chaos. Harvard Business Review, 63, 73- 84 .

Quinn, J. B. (1999). Strategic outsourcing: Leveraging knowledge capabilities. Sloan Management Review, 40, 9-21.

Quinn, J. B. (2000). Outsourcing innovation: The new engine of growth. Sloan Management Review, 41, 13-28.

Reilly, R. F., \& Schweihs, R. P. (1999). Valuing intangible assets. New York : McGraw-Hill. 
Riahi-Belkaoui, A. (2004). Accounting Theory. (5th ed.). Andover: South-Western.

Rosenberg, N. \& Hagén, H-O. (2003). The responsiveness of the universities. Östersund: Swedish Institute for Growth Policy Studies (ITPS:A2003:019).

Roussel, P. A., Saad, K. N., \& Erickson, T. J. (1991). Third generation R\&D: Managing the link to corporate strategy. Boston: Harvard Business School Press.

Schiller, S. (2010). Management Accounting in a Learning Environment. Journal of $\begin{array}{lllll}\text { Accounting } \quad \& \quad \text { Chanizational } & \text { Change, } & \text { 123-148. }\end{array}$ http://dx.doi.org/10.1108/18325911011025722

Schiller, S. (2012). Importance of managing intangible assets in enhancing dynamic capabilities of firms: cases from Sweden and Germany. Annals of Innovation \& Entrepreneurship, 2012, 3, 17292.

Schiller, S., Perera, H., Rendahl, J. E., \& Enquist, H. (2004). What factors explain the degree of innovativeness in large, established firms and in fast-growing firms - towards a new theory of management of innovation. Paper presented at EIASM: The 11th International Product Development Management Conference (IPDMC), June 20-22, 2004, Dublin, Ireland.

Scott, G. M. (2000). Critical technology management issues of new product development in high-tech companies. Journal of Product Innovation Management, 17, 57-77. http://dx.doi.org/10.1016/S0737-6782(99)00012-0

Shillito, M. (1994). Advanced QFD: Linking technology to market and company needs. New York: John Wiley \& Sons.

Skinner, D. J. (2008). Accounting for intangibles: a critical review of policy recommendations. Accounting and Business Research, 38, 191-204. http://dx.doi.org/10.1080/00014788.2008.9663332

Teece, D. J. (1998). Design issues for innovative firms: bureaucracy, incentives and industrial structure. In A. D. Jr. Chandler, P. Hagström, \& Ö. Sölvell (Eds.), The dynamic firm: the_role of technology, strategy, organization, and regions (Chapter 7). Oxford: Oxford University Press. http://dx.doi.org/10.1002/smj.640

Teece, D. J. (2000). Managing intellectual capital: organizational, strategic, and policy dimensions. Oxford: Oxford University Press.

Teece, D. J. (2007). Explicating dynamic capabilities: the nature and microfoundations of (sustainable) enterprise performance. Strategic Management Journal, 28, 1319-1350.

Teece, D. J., Pisano, G., \& Shuen, A. (1990). Firm capabilities, resources and the concept of strategy. Economic Analysis and Policy Working paper EAP 38, University of California. http://dx.doi.org/10.1002/(SICI)1097-0266(199708)18:7\%3C509::AID-SMJ882\%3E3.0.CO; $2-\mathrm{Z}$

Teece, D. J., Pisano, G., \& Shuen, A. (1997). Dynamic capabilities and strategic management. Strategic Management Journal, 18, 509-533. 


\section{Macrothink}

Research in Business and Management

ISSN 2330-8362

2014, Vol. 1, No. 1

Tidd, J., \& Trewhella, M. (1997). Organizational and technological antecedents for knowledge acquisition and learning. $R \& D$ Management, 27, 359-375. http://dx.doi.org/10.1111/1467-9310.00071

Tidd, J., Bessant, J., \& Pavitt, K. (2005). Managing innovation: integrating technological, market and organizational change (3rd ed.). Chichester: John Wiley \& Sons.

Trompenaars, F., \& Hampden-Turner, C. (2012). Riding the waves of culture: Understanding cultural diversity in business (3rd ed.). London: Nicholas Brealey Publishing.

Trott, P. (2011). Innovation management and new product development (5th ed.). London: Prentice Hall.

Upton, W. S. (2001). Business and financial reporting: challenges from the new economy. Special Report, No. 219-A, April 2001, Financial Accounting Standards Board.

Von Hippel, R. (1990). Task partitioning: an innovation process variable. Research Policy, 19, 407-418. http://dx.doi.org/10.1016/0048-7333(90)90049-C

Westhead, P. (1997). R\&D 'inputs' and 'outputs' of technology-based firms located on and off science parks. R\&D Management, 27, 45-61. http://dx.doi.org/10.1111/1467-9310.00041

Wheelwright, S. C., \& Clark, K. B. (1995). Leading product development: the senior manager's guide to creating and shaping the enterprise. New York: Free Press.

Williamson, O. E. \& Winter, S. G. (Eds.). (1991). The nature of the firm: Origins, evolution, and development. New York: Oxford University Press.

Åkerlind, G. S. (2005). Variation and commonality in phenomenographic research methods. Higher Education Research \& Development, 24, 321-334. http://dx.doi.org/10.1080/07294360500284672

\section{Appendix}

Appendix 1. The formulated corporate innovation platform

Based on an extensive literature review the following corporate innovation platform has been formulated (see below). Taken together, this model of factors assuming to affect the degree of innovativeness in firms listed on the NASDAQ OMX Stockholm forms the theoretical foundation on which a survey instrument is designed and submitted to a selection of firms.

Dependent variable

The dependent variable, the degree of innovativeness, being an inherently complex and uncertain phenomenon, is measured by and described from three different aspects, of which one is the development aspect (measured as time-to-market), while another is the economic contribution aspect (measures as margin per new product). A third aspect is referable to the research activity (measured as number of patents, or innovations per new product). 


\section{Macrothink}

Independent variables

The study of innovation management is a very broad subject, where no single approach provides all the answers. This indicates the need to include and relate a rather extensive set of factors (independent variables) to each identified aspect of innovativeness. From reviewing the literature, twenty independent variables have been identified as potential determinants of innovation, of which corporate strategy is the first.

\section{Corporate strategy}

See e.g., Trott, 2011; Pavitt, 1990; Andrews, 1998; Dessant and Tidd, 2011.

$\underline{\text { Management model including measurement system }}$

See e.g., Andrews, 1998; Mintzberg, 1998; Adler, 1999; Schiller, 2010; Schiller and Perera, 2012; Nixon, 1998.

\section{General economic outlook}

See e.g., Andrews, 1998; Johnson and Scholes, 1993; Krugman, 2009.

Education and knowledge level/R\&D

See e.g., Penrose, 1959; Cohen and Levinthal, 1990; Teece, 1998, 2000; Dessant and Tidd, 2011; Mansfield, 1969; Pavitt, 1991; Schiller, 2010.

Corporate culture

See e.g., Quinn, 1985; Oden, 1997; O’Reilly, 1989; Teece, 2000; Trompenaars and Hampden-Turner, 2012.

\section{Corporate social responsibility}

See e.g., Henderson, 2001; Friedman, 1997; Carroll et al., 2012; Buchholz and Rosenthal, 2002 .

\section{Organizational structure of R\&D}

See e.g., Oden, 1997; Roussel, et al., 1991; Adler, 1999; Karlsson and Åhlström, 1997.

Alliance/partnership/innovation networks/licensing with other companies

See e.g., Dessant and Tidd, 2011; McGee and Dowling, 1994; Das and Teng, 2003; Mothe and Link, 2002.

$\underline{\text { Research collaboration with universities, research institutes, etc. }}$

See e.g., Tidd and Trewhella, 1997; Cohen and Levinthal, 1990; Rosenberg and Hagén, 2003.

Outsourcing of R\&D/innovation capacity

See e.g., Quinn, 1999, 2000; Williamson and Winter, 1991; Narayanan, 2001; D'Aveni and Ravenscraft, 1994. 


\section{Macrothink}

Competitive environment/market position

See e.g., Porter, 1985, 1996, 1998; Dessant and Tidd, 2011.

Cost, time and risk of $\mathrm{R} \& \mathrm{D} /$ innovation activities

See e.g., Nixon, 1998; Roussel, et al., 1991; Clark and Fujimoto, 1991; Jagersma, 2003.

Integration and coordination between the senior and middle management level

See e.g., Quinn, 1985; Roussel, et al., 1991; Wheelwright and Clark, 1995; Oden, 1997.

Integration and coordination of the marketing and R\&D function

See e.g., Leenders and Wierenga, 2001; Cooper and Kleinschmidt, 1993; Shillito, 1994;

Sounder and Moenaert, 1992.

Methods of funding R\&D

See e.g., Teece, 2000; Roussel, et al., 1991; Mitchell and Hamilton, 1988; Cohen and Levinthal, 1990.

\section{Proximity to Science Park}

See e.g., Dabinett, 1995; Massey, et al., 1991; Westhead, 1997; Link and Link, 2003.

Involvement of senior management in the $\mathrm{R} \& \mathrm{D}$ process

See e.g., Clark and Fujimoto, 1991; Wheelwright and Clark, 1995; Quinn, 1985; Oden, 1997; Gomes et al., 2001.

Involvement of customers/users/suppliers in the R\&D process

See e.g., Von Hippel, 1990; Christensen and Bower, 1995; Daily, 1996; Leonard-Barton and Sinha, 1993.

Evaluating and rewarding R\&D activities

See e.g., Nixon, 1998; Cooper and Slagmulder, 1999; Teece, 1999; Crawford, 1997.

Integration and coordination between idea generation and concept evaluation

See e.g., Jagersma, 2003; Oden, 1997; Dessant and Tidd, 2011; Wheelwright and Clark, 1995.

Appendix 2

\section{Dev1 - Observed relations related to time-to-market (development lead time)}

(Dev1-A) Competitive Environment/Market Position correlates with General economic outlook (in terms of time-to-market) 
(Dev1-B) Competitive Environment/Market Position correlates with Systems for Evaluation and Reward/Personnel Policy (in terms of time-to-market)

\section{Dev2 - Observed relations related to time-to-market (development lead time)}

(Dev2-A) Involvement of customers/users/suppliers in the $\mathrm{R} \& \mathrm{D} /$ innovation process correlates with Educational and knowledge level within the $\mathrm{R} \& \mathrm{D} /$ innovation function (in terms of time-to-market) - professional knowledge level

(Dev2-B) Involvement of customers/users/suppliers in the $\mathrm{R} \& \mathrm{D} /$ innovation process correlate with Integration and coordination of the Marketing and $R \& D /$ innovation function (in terms of time-to-market)

(Dev2-C) Involvement of customers/users/suppliers in the R\&D/innovation process correlate with Methods of funding R\&D/innovation activities (in terms of time-to-market)

\section{Fin3 - Observed relations related to margin per new product}

(Fin3-A) Competitive Environment/Market Position correlates with Margin per new product

(Fin3-B) Competitive Environment/Market Position correlates with Corporate strategy (in terms of margin per new product)

(Fin3-C) Competitive Environment/Market Position correlates with Management model including the measurement system (in terms of margin per new product)

\section{Fin4 - Observed relations related to margin per new product}

(Fin4-A) Involvement of customers/users/suppliers in the R\&D/innovation process correlates with Management model - including the measurement system (in terms of margin per new product)

(Fin4-B) Involvement of customers/users/suppliers in the R\&D/innovation process correlates with Educational and knowledge (professional knowledge) level within the R\&D/innovation function (in terms of margin per new product)

(Fin4-C) Involvement of customers/users/suppliers in the R\&D/innovation process correlates with Proximity to Science Park (in terms of margin per new product)

(Fin4-D) Involvement of customers/users/suppliers in the R\&D/innovation process correlates with Involvement of senior management in $\mathrm{R} \& \mathrm{D} /$ innovation process (in terms of margin per new product)

(Fin4-E) Involvement of customers/users/suppliers in the R\&D/innovation process correlates with Integration and coordination between idea generation and product development (in terms of margin per new product)

\section{Res5 - Observed relations related to number of patents/innovations per new product}

(Res5-A) Corporate Culture/innovation climate correlate with Methods of funding $\mathrm{R} \& \mathrm{D} /$ innovation activities (in terms of number of patents/innovations per new product) 


\section{Macrothink}

\section{Res6 - Observed relations related to number of patents/innovations per new product}

(Res6-A) Corporate strategy correlates with Management model - including the measurement system (in terms of number of patents/innovations per new product)

(Res6-B) Corporate strategy correlates with Alliance/partnership/innovation networks/licensing with other companies (in terms of number of patents/innovations per new product)

(Res6-C) Corporate strategy correlates with Methods of funding R\&D/innovation activities (in terms of number of patents/innovations per new product)

Appendix 3. Observed relations in large technical companies (LTC), medium-sized technical companies (MTC), and in a large medical technology company (LMTC)

\begin{tabular}{|c|c|c|c|c|c|c|c|c|c|c|c|c|c|c|c|c|c|}
\hline \multirow[b]{2}{*}{ Respondent } & \multicolumn{2}{|c|}{ Dev1 } & \multicolumn{3}{|c|}{ Dev2 } & \multicolumn{3}{|c|}{ Fin 3} & \multicolumn{5}{|c|}{ Fin4 } & \multirow{2}{*}{$\begin{array}{c}\text { Res5 } \\
\mathrm{A} \\
\end{array}$} & \multicolumn{3}{|c|}{ Res6 } \\
\hline & A & $\mathrm{B}$ & A & $\mathrm{B}$ & $\mathrm{C}$ & A & $\mathrm{B}$ & $\mathrm{C}$ & A & $\mathrm{B}$ & $\mathrm{C}$ & D & E & & $\mathrm{A}$ & $\mathrm{B}$ & $\mathrm{C}$ \\
\hline F1 (LTC) & 2,5 & 2,5 & 3,5 & 1,5 & 4 & 1 & 2 & 2 & 3 & 5 & 6 & 2 & 5 & 3 & 3 & 2 & 3 \\
\hline F2 (LTC) & 3 & 3 & 2 & 2 & 4 & 2 & 2 & 2 & 2 & 3 & 5 & 2 & 4 & 3 & 3 & 5 & 2 \\
\hline F3 (LTC) & 2 & 6 & 6 & 2 & 4 & 1 & 2 & 6 & 2 & 5 & 6 & 2 & 3 & $\{\mathrm{n} / \mathrm{a}\}$ & 4 & 3 & 3 \\
\hline F4 (LTC) & 3 & 3 & 2 & 2 & 4 & 2 & 3 & 2 & 1 & 3 & 4 & 3 & 2 & 4 & 3 & 2 & 2 \\
\hline F5 (MTC) & 2,5 & 3 & 1 & 2 & 3 & 5 & 3 & 4 & 5 & 3 & 4 & 2 & 3 & 2 & 5 & 3 & 2 \\
\hline F6 (MTC) & 2,5 & 2 & 1 & 2 & 1 & 4,5 & 2 & 4,5 & 2 & 4 & 3 & 1 & 2 & 2 & 2 & 2 & 2,5 \\
\hline F7 (LTC) & $\{\mathrm{n} / \mathrm{a}\}$ & $\{\mathrm{n} / \mathrm{a}\}$ & 2 & 2 & 1 & 1 & 1 & 2 & 1 & 2 & 1 & 2 & 1 & 1 & 2 & 2 & 2 \\
\hline F7 (LTC) & $\{n / a\}$ & $\{n / a\}$ & 1 & 2 & 1 & 1 & 1 & 2 & 2 & 2 & 2 & 1 & 1 & 1 & 1 & 2 & 1 \\
\hline F8 (LMTC) & $\{\mathrm{n} / \mathrm{a}\}$ & $\{\mathrm{n} / \mathrm{a}\}$ & 3 & 3 & 5 & 5,5 & 3 & 3 & 4 & 3 & 5 & 3 & 3 & 3 & 2 & 3,5 & 3 \\
\hline F9 (LTC) & 2 & 4 & 2 & 2 & 4 & 1 & 2 & 6 & 2 & 3 & 5 & 2 & 3 & 2 & 5 & 3 & 6 \\
\hline F10 (MTC) & 4 & $\{\mathrm{n} / \mathrm{a}\}$ & 2 & 2 & 4 & 4 & 2 & 2 & 2 & 3 & 2 & 2 & 2 & 3 & 2 & $\{\mathrm{n} / \mathrm{a}\}$ & 4 \\
\hline Median= & 2,5 & 3 & 2 & 2 & 4 & 2 & 2 & 2 & 2 & 3 & 4 & 2 & 3 & 2,5 & 3 & 2,5 & 2,5 \\
\hline$n=$ & (8) & $(-7)$ & (11) & 11) & & 11) & (11) & (11 & $(11)$ & (11) & (11) & & & (10) & (11) & $(10)$ & (11) \\
\hline
\end{tabular}

Appendix 4. Balancing factors related to Res6-B (patent/innovation per new product)

\section{Res6-B (patent/innovation per new product)}
A. Intellectual Work
B. Communication
C. Know-how
D. Management
E. Networking
F. Strategy
G. System

\section{GENERALOBSERVED RELATION}

[General dynamic capability] 


\section{Macrothink

\section{A. Intellectual Work}

1. Taking out a patent for the underlying technological knowledge in order not to set a standard versus not taking out a patent for the underlying technological knowledge in order to set a standard

\section{B. Communication}

4. What information is possible to publish versus not to publish

C. Know-how

6. Controlling the knowledge oneself versus making the knowledge accessible to all

11. Acquiring the knowledge from User Conference versus acquiring the knowledge in other ways

12. Reaching solutions to problems within alliances versus reaching solutions in competition with others

\section{Management}

8. General professional instructions for cooperating together with external partners versus instructions related to individual project

\section{E. Networking}

3. Cooperating together with external partners within a specific area of interest versus cooperating within more general areas of interest

5. Cooperating together with others, including competitors, versus cooperating together with non-competitors

9. Cooperation within a network versus cooperation on an individual basis

10. Cooperation at a user level versus cooperation at a systemic level

13. Being engaged in a short-term alliance versus being engaged in a long-term alliance

\section{F. Strategy}

2. Give precedence to a niche strategy or to a cost strategy

\section{G. System}

7. Systems compatibility being important versus not being important 
Appendix 5. Balancing factors, all observed relations [Dev1 - Res6]

\begin{tabular}{|l|l|l|l|l|l|}
\hline \multicolumn{2}{|l|}{ Factor Level I [7-16] } & \multicolumn{2}{l|}{ Factor Level II [5-6] } & \multicolumn{2}{l|}{ Factor Level III [1-4] } \\
\hline Know-how/Intellectual Work & 16 & Financial & 5 & Project & 4 \\
\hline Corporate Operation & 7 & Strategy & 5 & Culture & 3 \\
\hline Management & 7 & & & Networking & 3 \\
\hline Product Development & 7 & & & Ownership Structure & 3 \\
\hline Product Characteristic & 7 & & & System & 3 \\
\hline & & & & Communication & 2 \\
\hline & & & & Customer & 2 \\
\hline & & & & Market & 2 \\
\hline & & & & Trend & 2 \\
\hline
\end{tabular}

Appendix 6. Observed relations related to development [Dev1 - Dev2]

\begin{tabular}{|l|l|l|l|l|l|}
\hline \multicolumn{2}{|l|}{ Factor Level I [7-15] } & \multicolumn{2}{l|}{ Factor Level II [5-6] } & \multicolumn{2}{l|}{ Factor Level III [1-4] } \\
\hline Know-how/Intellectual Work & $2(16)$ & Financial & $2(5)$ & Project & $1(4)$ \\
\hline Corporate Operation & $0(7)$ & Strategy & $1(5)$ & Culture & $1(3)$ \\
\hline Management & $1(7)$ & & & Networking & $1(3)$ \\
\hline Product Development & $3(7)$ & & & Ownership Structure & $1(3)$ \\
\hline Product Characteristic & $2(7)$ & & & System & $0(3)$ \\
\hline & & & & Communication & $0(2)$ \\
\hline & & & & Customer & $2(2)$ \\
\hline & & & & Market & $1(2)$ \\
\hline & & & & Reward & $1(2)$ \\
\hline
\end{tabular}


Appendix 7. Observed relations related to margin per new product [Fin3 - Fin4]

\begin{tabular}{|c|c|c|c|c|c|}
\hline \multicolumn{2}{|l|}{ Factor Level I [7-15] } & \multicolumn{2}{|c|}{ Factor Level II [5-6] } & \multicolumn{2}{|c|}{ Factor Level III [1-4] } \\
\hline Know-how/Intellectual Work & $6(16)$ & Financial & $1(5)$ & Project & 1(4) \\
\hline Corporate Operation & $5(7)$ & Strategy & $2(5)$ & Culture & $0(3)$ \\
\hline Management & $3(7)$ & & & Networking & $0(3)$ \\
\hline Product Development & $3(7)$ & & & Ownership Structure & $0(3)$ \\
\hline \multirow[t]{6}{*}{ Product Characteristic } & $3(7)$ & & & System & $1(3)$ \\
\hline & & & & Communication & $1(2)$ \\
\hline & & & & Customer & $0(2)$ \\
\hline & & & & Market & $0(2)$ \\
\hline & & & & Trend & $0(2)$ \\
\hline & & & & Reward & $0(1)$ \\
\hline
\end{tabular}

Appendix 8. Observed relations related to level of innovation [Res5 - Res6]

\begin{tabular}{|c|c|c|c|c|c|}
\hline \multicolumn{2}{|l|}{ Factor Level I [7-15] } & \multicolumn{2}{|c|}{ Factor Level II [5-6] } & \multicolumn{2}{|c|}{ Factor Level III [1-4] } \\
\hline Know-how/Intellectual Work & $8(16)$ & Financial & $2(5)$ & Project & $2(4)$ \\
\hline Corporate Operation & $2(7)$ & Strategy & $2(5)$ & Culture & $2(3)$ \\
\hline Management & $3(7)$ & & & Networking & $2(3)$ \\
\hline Product Development & $0(7)$ & & & Ownership Structure & 2(3) \\
\hline \multirow[t]{6}{*}{ Product } & $2(7)$ & & & System & 2(3) \\
\hline & & & & Communication & $0(2)$ \\
\hline & & & & Customer & $0(2)$ \\
\hline & & & & Market & $1(2)$ \\
\hline & & & & Trend & $1(2)$ \\
\hline & & & & Reward & $0(1)$ \\
\hline
\end{tabular}




\section{Macrothink

Appendix 9. An exempt from the Interview Guide

Dev1- Observed relations related to time-to-market (development lead time)

$\underline{\text { Dev1 }}$

Competitive Environment/Market Position correlates with:

1 General economic outlook $*, n=40$

(Positive)

2 Systems for Evaluation and Reward/Personnel Policy **, $\mathrm{n}=40$

(Negative)

(Dev1-A) -To what extent do you agree with the following statement?

Competitive Environment/Market Position correlates with General economic outlook (in terms of time-to-market)

(1) Strongly agree

(1)

(2)

(3)
(4) Neither agree or disagree

(5)

(6)
(7) Strongly disagree

-Correlates in what direction?

-Does the strength of the association change over time, if so, under what circumstances?

-Can you give an example of how Competitive Environment/Market Position may correlate with General economic outlook?

\section{Copyright Disclaimer}

Copyright reserved by the author(s).

This article is an open-access article distributed under the terms and conditions of the Creative Commons Attribution license (http://creativecommons.org/licenses/by/3.0/). 